\title{
Energy, Exergy and Efficiency Analysis of a Flat Plate Solar Collector Used as Air Heater
}

(Analisis Tenaga, Eksergi dan Kecekapan Pengukur Solar Plat Rata yang Digunakan sebagai Pemanas Air)

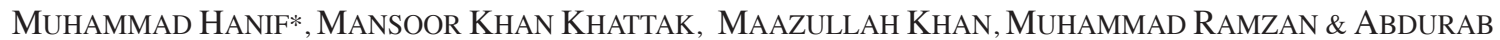

\begin{abstract}
Air heating by solar collectors is renewable technology providing hot air for different purposes. The present research emphasizes on analysis of energy, exergy and efficiency of a flat plate solar air heater. The analysis model was tested on five different air mass flow rates of 0.5 (Natural), 1.31, 2.11, 2.72 and $3.03 \mathrm{kgs}^{-1}$ under three different tilt angles of 25, 35 (Recommended) and 50 . The data was replicated three times making a total of 45 treatments. A two factorial completely randomized design was used to find if there is any significant difference among the treatments. The results showed that the solar collector gave better performance at air mass flow of $3.03 \mathrm{kgs}^{-1}$ under tilt of $35^{\circ}$. At maximum air mass flow rate of $3.03 \mathrm{kgs}^{-1}$ and optimum tilt angle of $35^{\circ}$ the maximum energetic efficiency of 51\%, while minimum exergetic efficiency of $24 \%$ and maximum overall efficiency of $71 \%$ were recorded. It was concluded that to get maximum thermal efficiencies of $71 \%$ from flat plate solar collector used as an air heater must be operated at high air mass flow rates of $3.03 \mathrm{kgs}^{-1}$ under $35^{\circ}$ tilt angle at Peshawar, Pakistan.
\end{abstract}

Keywords: Efficiency; energy; exergy; flat plate solar collector

\section{ABSTRAK}

Pemanasan udara oleh pengumpul suria merupakan teknologi yang boleh diperbaharui yang menyediakan udara panas untuk tujuan berbeza. Penyelidikan yang terkini menekankan tentang analisis tenaga, eksergi dan kecekapan plat rata pemanas udara solar. Model analisis diuji pada lima kadar aliran jisim udara yang berbeza iaitu 0.5 (semula jadi), 1.31, 2.11, 2.72 dan $3.03 \mathrm{kgs}^{-1}$ di bawah tiga sudut kecondongan 25, 35 (disyorkan) dan 50 . Data uji kaji diulang sebanyak tiga kali merangkumi 45 rawatan secara total. Reka bentuk dua rawak faktorial digunakan untuk mencari perbezaan yang signifikan antara rawatan. Keputusan uji kaji menunjukkan bahawa pengumpul suria memberikan prestasi yang lebih baik pada aliran jisim udara $3.03 \mathrm{kgs}^{-1}$ di bawah kecondongan $35^{\circ}$. Pada kadar aliran jisim maksimum udara 3.03 $\mathrm{kgs}^{-1}$ dan sudut kecondongan optimum 35 , keputusan kecekapan energetik maksimum ialah 51\%, manakala kecekapan eksergi ialah minimum 24\% dan kecekapan keseluruhan maksimum pula ialah 71\%. Kesimpulannya, untuk mendapatkan kecekapan terma maksimum $71 \%$ daripada pengumpul suria plat rata yang digunakan sebagai pemanas udara, ia mesti dikendalikan pada kadar aliran jisim udara tinggi $3.03 \mathrm{kgs}^{-1}$ di bawah kecondongan $35^{\circ}$ di Peshawar, Pakistan.

Kata kunci: Eksergi; kecekapan; pengumpul plat rata; tenaga

\section{INTRODUCTION}

Energy is the base of economic and social development. The timely increasing demand of energy and limitations of fossil fuels reservoirs is a serious issue for the world particularly in Pakistan. Increase in the demand of fossil fuels for energy production and their impact on the environment is now a global problem which led to a significant enhanced trend of acquiring renewable energy sources. Renewable energy sources have the potential to overcome the problems of energy demand and environment destruction by greenhouse gases emitting by the using fossil fuels. It is thus widely investigated that renewable energy can play a vital role in any field where energy is a primary source. Renewable energy resources have a potential to replace the non-renewable energy resources if properly worked out and installed according to the demand with all the engineering aspects needed for their maximum output (Koca et al. 2014). Renewable energy has many sources, among them solar energy is a clean, abundant and environment friendly source which has received considerable attention for generating heat and electricity. It can be converted into heat and electricity using different solar conversion technologies namely flat plate solar collector, concentration solar collector and photovoltaic technologies. For heating purposes flat plate solar collectors and parabolic trough solar collectors are the main component for solar thermal heating. The flat plate solar collectors are used mainly for low thermal systems of agricultural and domestic heating requirements while the parabolic trough concentrating solar collector technology is used for high thermal systems like steam and power generation (Hanif et al. 2014; Kalogirou et al. 2016).

Before installing a thermal solar system for a specific purpose, it is most important to analyse the performance of 
these collectors. The efficiency for a solar thermal system is the key for its maximum thermal performance. But to determine the performance of the system the efficiency equation alone does not determines the internal losses by the solar collectors. Only calculating efficiency is not the sufficient criteria for finding optimum performance of a solar collector. For this, an analysis based on second law of thermodynamics is best to determine the exergy analysis of the solar system. Exergy analysis is a vital and most necessary parameter for optimization of design and future operation of the solar thermal collectors. Solar thermal collectors must have been examined in terms of their energy and exergy, efficiency and entropy generation for optimal performance (Ge et al. 2014; Farahat et al. 2009), discussed the optimal and critical operations of different solar collectors by means of energy and exergy analysis. They concluded that an optimal operational model at any state is not useful for performance analysis. It's not a complete setup of generalizing and optimizing the solar collector performance. Hence an advanced model with solving common errors for energy and exergy analysis is required for computing efficiencies of solar collectors. The performance must be tested at dynamic models and energy and exergy analysis must be carried out at transient states. Many authors reported their work on optimizing the performance of solar collectors and they have concluded that solar collectors showed a lot of difficulties at steady state conditions. Thus, it is recommended to develop and test the solar thermal collectors at transient states for achieving better results of energy and exergy analysis (Hamed et al. 2014).

To test a solar collector like concentrating dish or parabolic trough type solar collectors for energy and exergy analysis, it is necessary to keep in mind that the sky must be clear, the flow rate must be constant, assume the properties of material of construction of the solar collector as constant, the glazing must have more than $85 \%$ transmittance, the fluid velocity must be uniform, the losses by reflection are assumed to be negligible and the air gap between the absorber and glazing must be transparent. Keeping in view these energy and exergy analysis for solar collectors must be carried out (Jafarkazmi \& Ahmadifard 2013).

Keeping in view the above-mentioned facts in the literature, the present research study is designed to investigate the energy and exergy analysis of flat plate solar collector used as an air heater. The objective of the research was to investigate the sole and interaction effects of air mass flow rates and tilt angles of the solar collector energy, exergy and efficiency.

\section{MATERIALS AND METHODS}

\section{SITE SELECTION}

The solar collector assembly was installed on the roof of the Department of Agricultural Mechanization, The University of Agriculture Peshawar, Khyber Pakhtunkhwa, Pakistan. The Latitude, Longitude and elevation of the site are $34.0204^{\circ}, 71.4822^{\circ}$ and $448.3608 \mathrm{~m}$ respectively. The site is said to be perfect because it receives maximum solar irradiance from dawn to dusk without interference of any shadow of a structure.

\section{THE THERMAL SOLAR COLLECTOR}

The environmental and design conditions and parameters of the solar collector that will be used in the experiment are given in Table. 1. The flat plate solar collector that was used in the experiment is shown in Figure 1 and drawing of the flat plate solar collector assembly is given in Figures 2, 3 and 4 .

\section{RECORDING SOLAR IRRADIANCE}

The data of daily diffused solar irradiance was recorded by the help of digital Pyranometer (Solar Power Meter, TES1333, Taiwan) as shown in Figure 1. The environmental conditions of the site were as given in Table 1 .

TABLE 1. Average meteorological data of the site during the time of recording of solar irradiance

\begin{tabular}{ccc}
\hline $\begin{array}{c}\text { Local time } \\
(\mathrm{h})\end{array}$ & $\begin{array}{c}\text { Ambient temperature } \\
\left({ }^{\circ} \mathrm{C}\right)\end{array}$ & $\begin{array}{c}\text { Air velocity } \\
\left(\mathrm{m} . \mathrm{s}^{-1}\right)\end{array}$ \\
\hline $9: 00$ & 30.6 & 2.1 \\
$10: 30$ & 36.7 & 2.5 \\
$11: 00$ & 40.1 & 2.4 \\
$12: 00$ (Noon) & 40.5 & 2.7 \\
$1: 00$ pm & 40.2 & 2.1 \\
$2: 00$ & 38.3 & 2.6 \\
$3: 00$ & 37.5 & 2.2 \\
$4: 00$ & 36.6 & 3.1 \\
$5: 00$ & 31.5 & 3.3 \\
\hline
\end{tabular}

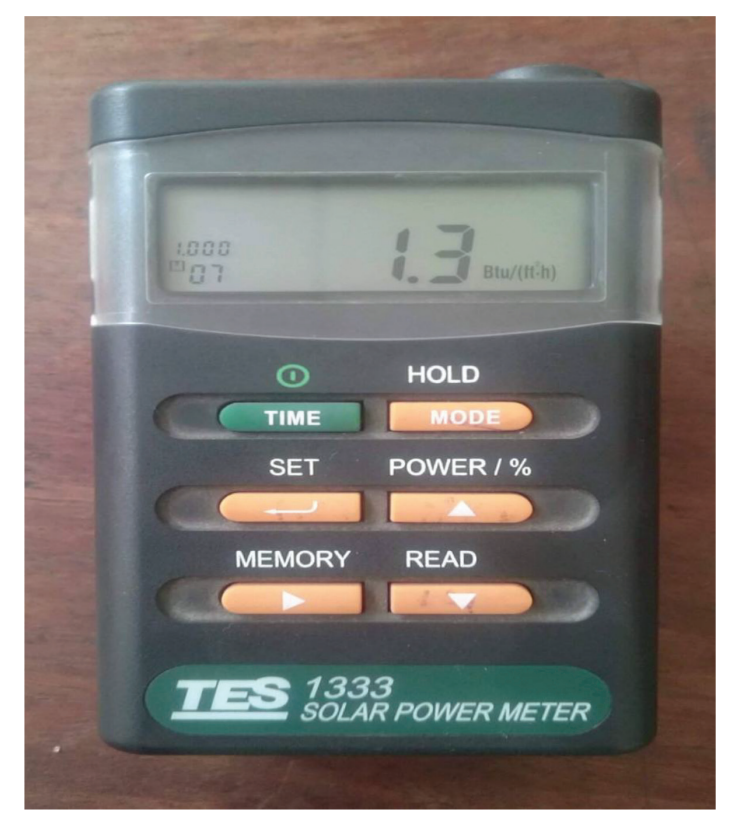

FIGURE 1. Pyranometer used in the experiment 


\section{ENERGY AND EXERGY ANALYSIS}

When the solar collector is at equilibrium with the environment then the general form of energy and exergy balance equation of the system is given by Bellos et al. (2016),

$$
E_{\text {in }}+E_{s}+E_{\text {out }}+E_{1}+E_{d}=0
$$

TABLE 2. Design and environmental conditions of the flat plate solar collector

\begin{tabular}{|c|c|}
\hline Parameters & Value \\
\hline Collector's length, width and depth & $3.40,2.46 \& 0.66 \mathrm{~m}$ \\
\hline Area & $8.365 \mathrm{~m}^{2}$ \\
\hline Volume of the solar collector & $5.520 \mathrm{~m}^{3}$ \\
\hline Absorber & $\begin{array}{l}\text { V-corrugated, Black } \\
\text { painted with header } \\
\text { raiser pipes }\end{array}$ \\
\hline Absorber area & $8.360 \mathrm{~m}^{2}$ \\
\hline Absorbance and transmittance of absorber & 0.92 and 0.88 \\
\hline Glazing (single glass) & $0.008 \mathrm{~m}(8 \mathrm{~mm})$ \\
\hline Agent fluids & Air and water \\
\hline Wind speed range & $0.1-35 \mathrm{~m} \mathrm{~s}^{-1}$ \\
\hline Collector tilt angles & $25^{\circ}, 35^{\circ}$ and $50^{\circ}$ \\
\hline Ambient temperature range & $283-810^{\circ} \mathrm{C}$ \\
\hline Apparent sun temperature & 4320 to $4350^{\circ} \mathrm{C}$ \\
\hline Absorber thickness & $0.0024 \mathrm{~m}(2.4 \mathrm{~mm})$ \\
\hline Optical efficiency & 0.88 \\
\hline Transmittance of glazing & 0.89 \\
\hline $\begin{array}{l}\text { Thickness of insulation } \\
\text { (Wood of deodar + polystyrene) }\end{array}$ & $0.15 \mathrm{~m}$ \\
\hline Thermal conductivity of absorber & $380 \mathrm{~W} \cdot \mathrm{m}^{-1} \cdot{ }^{\circ} \mathrm{C}^{-1}$ \\
\hline Solar irradiance range & $0-850 \mathrm{~W} \cdot \mathrm{m}^{-2}$ \\
\hline Tubes/ Pipes diameter (steel) & $0.025 \mathrm{~m}$ \\
\hline Flow rates & $0.1-3.5 \mathrm{~m} \mathrm{~s}^{-1}$ \\
\hline Volume of storage tank & $0.12 \mathrm{~m}^{3}$ \\
\hline Mass of water in storage tank & $120 \mathrm{~kg}$ \\
\hline Volume of head raised pipes & $0.086 \mathrm{~m}^{3}$ \\
\hline Mass of water in pipes & $86 \mathrm{~kg}$ \\
\hline Total volume of water in solar collector & $206 \mathrm{~kg}$ \\
\hline
\end{tabular}

Now we have to calculate each and every component of the (1). In detail to develop a model from the equation.

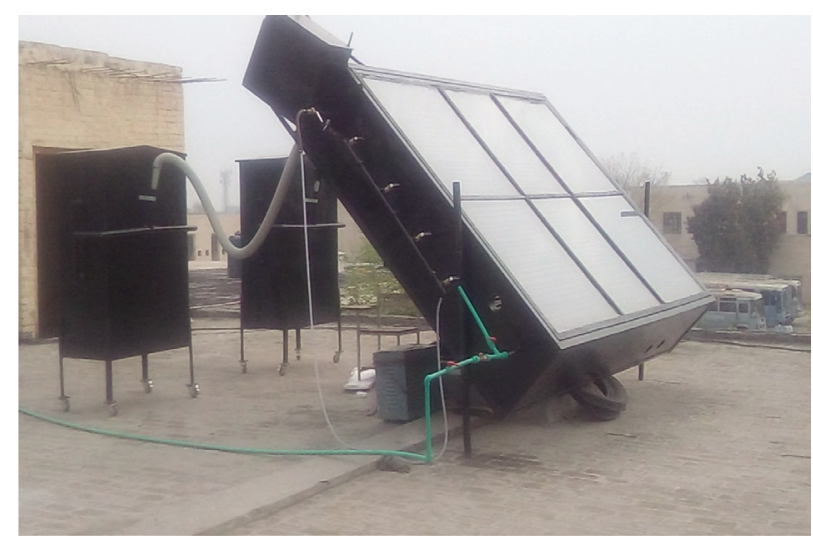

FIGURE 2. The flat plate solar collector assembly

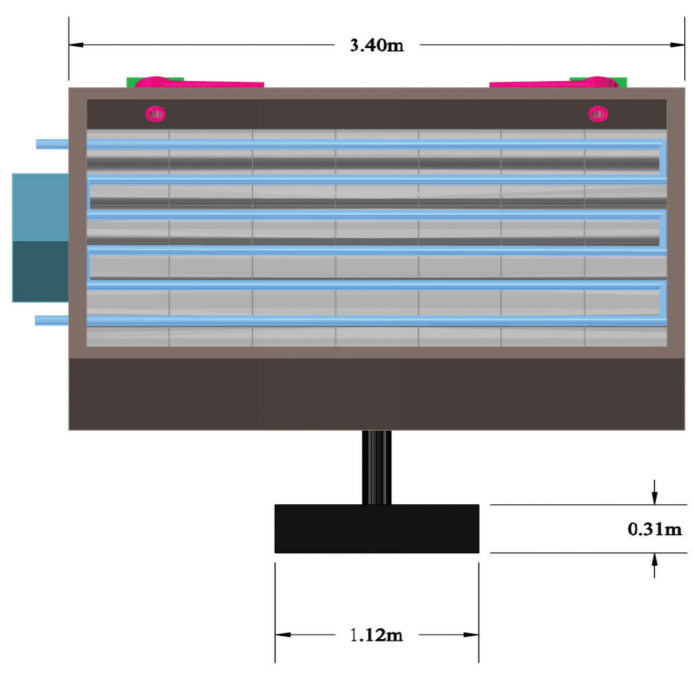

FIGURE 3. Front view of the flat plate solar collector

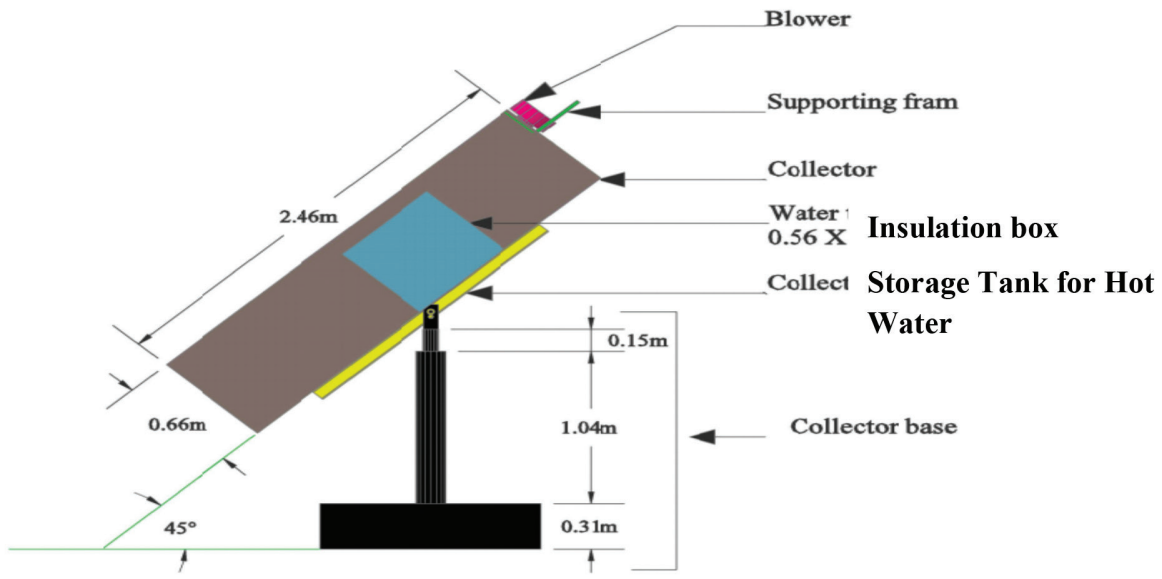

FIGURE 4. Side view of the flat plate solar collector 


\section{ENERGY ANALYSIS OF A THERMAL SOLAR COLLECTOR}

To calculate energy available to the solar collector, it is important to consider the energy gained equation by the working fluid. The equation is given by Al-Sulaiman (2013),

$$
\mathrm{Q}_{\mathrm{use}}=\mathrm{m}_{\mathrm{a}} \mathrm{C}_{\mathrm{p}} \Delta \mathrm{T} \quad \text { here } \Delta \mathrm{T}=\mathrm{Tout}-\mathrm{Ta}
$$

Now expending the equation for considering heat losses form the collector during the fluid flowing inside the solar collector to the atmosphere is given by HottedWhillies as (Calise et al. 2016),

$$
\mathrm{Q}_{\mathrm{use}}=\mathrm{A}_{\mathrm{abs}} \mathrm{Q}_{\mathrm{r}}\left[\mathrm{S}_{\mathrm{i}}-\mathrm{U}_{1}(\Delta \mathrm{T})\right] \text { here } \Delta \mathrm{T}=\mathrm{T}_{\mathrm{in}}-\mathrm{T}_{\mathrm{a}}
$$

where $S_{i}$ is the optical absorbed solar flux and $U_{1}$ is the heat lost by reflection, emittance and optical efficiency of glazing given by formula Farahat et al. (2009),

$$
\begin{aligned}
& \mathrm{Si}=\mathrm{T} \alpha \mathrm{IT} \\
& \mathrm{Q}_{\mathrm{R}}=\frac{m a C p}{U_{l} A_{a b s}}\left[1-\exp \left\{\frac{-F \phi U_{l} A_{a b s}}{m a C p}\right\}\right]
\end{aligned}
$$

Now putting (3) in (2), we get the overall equation of energy given to the collector and yielded by the absorber plate and is given by Islam et al. (2015),

$$
\mathrm{Q}_{\mathrm{use}}=\mathrm{A}_{\mathrm{abs}} \mathrm{S}_{\mathrm{i}}-\mathrm{U}_{1} \mathrm{~A}_{\mathrm{abs}}(\Delta \mathrm{T}) \text { here } \Delta \mathrm{T}=\mathrm{T}_{\mathrm{abs}}-\mathrm{T}_{\mathrm{a}}
$$

\section{EXERGY ANALYSIS OF A THERMAL SOLAR COLLECTOR}

Exergy is defined as the maximum amount of heat energy the solar collectors provide to driers by the help of fluid (air, water) flowing inside the solar collector.

Before calculating the exergy, we have to calculate the losses, stored or destroyed in the system.

\section{ENERGY STORED BY FLUIDS FLOWING IN THE SOLAR COLLECTOR}

The energy stored by the solar collector fluids is given by Jafarkazmi and Ahmadifard (2013),

$$
\mathrm{E}_{\mathrm{s}}=\mathrm{m}_{\mathrm{w}} \mathrm{C}_{\mathrm{p}} \Delta \mathrm{T}\left(\Delta \mathrm{T}=\mathrm{T}_{\mathrm{w}}-\mathrm{T}_{\mathrm{a}}\right)
$$

where $\mathrm{E}_{\mathrm{s}}$ represents the energy stored by the fluids for a specific period of time. In the solar collectors used in the experiment the $\mathrm{E}_{\mathrm{s}}$ is only for the water to be heated and stored in the water tank.

\section{ENERGY LEAKED BY THE SOLAR COLLECTOR}

The energy leaked from the solar collector is given by Jafarkazmi and Ahmadifard (2013)

$$
\mathrm{E}_{\mathrm{l}}=\left\{\mathrm{U}_{1} \mathrm{~A}_{\mathrm{abs}}\left(\mathrm{T}_{\mathrm{abs}}-\mathrm{T}_{\mathrm{a}}\right)\left(1-\frac{T a}{T a b s}\right)\right\}
$$

where $E_{1}$ represents the energy leaked by the solar collectors due to the material characteristics to lost heat.

\section{ENERGY DESTROYED BY THE SOLAR COLLECTOR}

The energy destroyed by the solar collector is given by Islam et al. (2015),

$$
\mathrm{E}_{\mathrm{d}}=-\mathrm{mC}_{\mathrm{P}} \mathrm{T}_{\mathrm{a}} \frac{\text { Tout }}{\text { Tin }} \mathrm{E}_{\mathrm{d}}=-\mathrm{mC}_{\mathrm{P}} \mathrm{T}_{\mathrm{a}}\left\{\ln \left(\frac{\text { Tout }}{\text { Tin }}\right)-\left(\frac{T_{\text {out }}-T_{\text {in }}}{T_{\text {abs }}}\right)\right\}
$$

where $E_{d}$ is the lost heat energy caused by the difference in temperature of absorber plate and fluids. It is the latent heat absorbed by the fluids in phase change.

\section{EXERGY OF THE SOLAR COLLECTOR}

Now the exergy of a solar collector is given by Kalogirou et al. (2016),

$$
E_{\text {out }}=\left[\left\{\left(m a C p\left(T_{\text {out }}-T_{a} T_{a} l_{n} \frac{T_{\text {out }}}{T_{a}}\right)-\frac{m \Delta P_{\text {out }}}{\rho}\right)+m w C p\left(T_{w}-T_{a}\right)\right\}\right]
$$

where $\mathrm{E}_{\text {out }}$ represent the energy to be loaded to the fluids and is the exergy of the system. It is also called as entropy of the solar collectors.

\section{EFFICIENCY OF A THERMAL SOLAR COLLECTOR}

It is ratio of energy output and useful energy available to the solar collectors. Now from (10). The second law of heat exchange efficiency equation of the solar collectors is by taking the ratio of (4) and (7). The overall equation is given by Ge et al. (2014),

$$
\eta=\frac{\operatorname{Aabs} \operatorname{Si}-\operatorname{UIAabs}(\Delta \mathrm{T})}{\left[\left\{\left(m a C p(T o u t-T a T a \ln \Delta T)-\frac{m \Delta P}{\rho}\right)+m w C p \Delta T\right\}\right]} \times 100
$$

\section{DATA LOGGERS}

Data loggers were installed on the solar collectors that recorded the solar irradiance, temperature of inlet and outlet, temperature inside the collector for $24 \mathrm{~h}$.

\section{STATISTICAL ANALYSIS}

The data was analyzed using two factorial Completely Randomized Design (C.R.D). The first factor was air mass flow rates with five levels and second was tilt angle of the solar collector with three levels. Both the factors were replicated three times (Hanif et al. 2016). The statistics were applied on energy, exergy and efficiency of the solar collector. 


\section{RESULTS AND DISCUSSIONS}

\section{SOLAR RADIATION}

The data regarding the solar irradiation on the site and other meteorological conditions that affected the performance of the solar collector are shown in Figure 5. The data showed that during the experimental period the site received more than $5000 \mathrm{~kW} \cdot \mathrm{m}^{-2}$ per month of solar irradiance at an average. This accounts more than $600 \mathrm{~W} \cdot \mathrm{m}^{-2}$ of solar power availability at the site. The data also shows that during the experimental period there was $50 \%$ relative humidity and $38^{\circ} \mathrm{C}$ ambient temperature which is far more best for drying different fruits and vegetables.

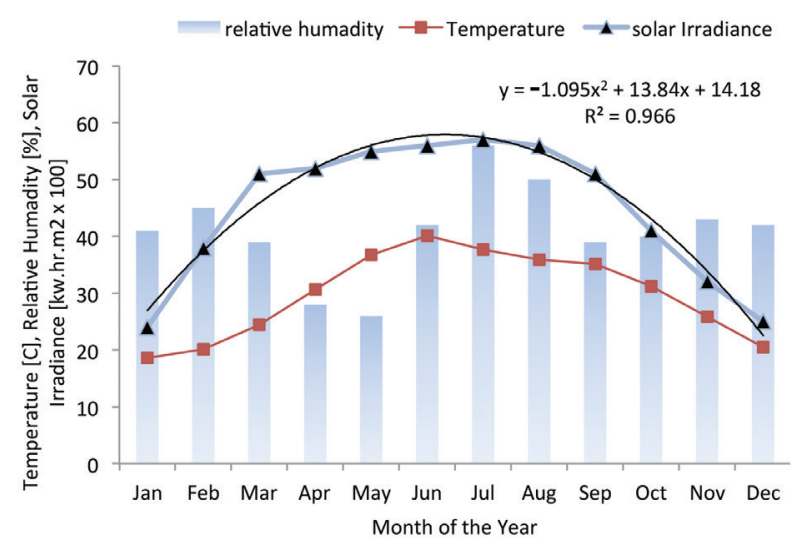

FIGURE 5. Relative humidity, temperature and solar irradiance of the site

\section{ENERGY EFFICIENCY}

Experimental data regarding the energy as affected by different air mass flow rates and tilt angles is given in Figure 6. The data in Figure 6 shows that increase in air mass flow rates will increase the energy efficiency of the solar collector. The increase in energetic efficiencies is due to improvement in convective heat transfer at higher flow rates. At natural or passive flow more, heat leaked from the collector as a result more energy is lost and solar collector was having low energetic efficiencies but as soon as the flow rates are made forced or convective, therefore, the solar collector energy improved by reducing leakage and loss of energy from the absorber through glazing to the environment. On the other hand, in collector tilt, an angle of $35^{\circ}$ gave maximum energy gained by the solar collector as compared to 25 or $50^{\circ}$ tilt. At natural flow the recorded energetic efficiencies were $33.3,37.5$ and $30.1 \%$ for 25 , 35 and $50^{\circ}$ tilt angles. As flow rates are increased and reached to maximum of $3.03 \mathrm{kgs}^{-1}$ therefore, the energetic efficiencies reached to $67.0,72.0$ and $61.5 \%$ for 25,35 and $50^{\circ}$ tilt angles. The results are in accordance with the findings of Al-Sulaiman (2014) and Bellos et al. (2016) who reported increase in energetic efficiency with increase in air mass flow through the solar collector. The efficiency of the present study is almost $10 \%$ higher than the finds of these authors. It is due to the size of the collector. They used 1.4 and $2.1 \mathrm{~m}^{2}$ collector which is 5 and 4 times smaller than the collector used in the present study having an area of $8.34 \mathrm{~m}^{2}$. The results are also in accordance with findings of Calise et al. (2016), Farahat et al. (2009) and Hanif et al. (2016) who reported the exergy increase with increase in air mass flow at tilt angle of 28 to $35^{\circ}$.

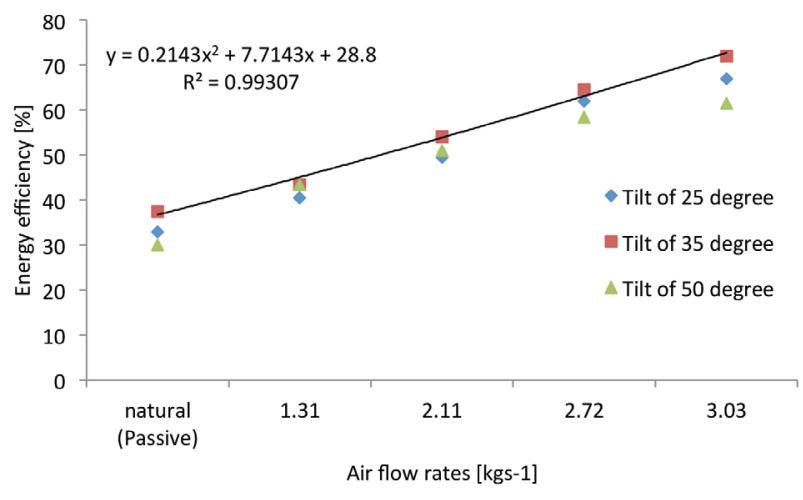

FIGURE 6. Energetic efficiencies of the flat plate solar collector as affected by air mass flow rates and tilt at different tilts of the solar collector

\section{EXERGY EFFICIENCY}

Experimental data regarding the exergy as affected by different air mass flow rates and tilt angles is given in Figure 7 . The data shows that the exegetic efficiencies of the flat plate solar collector decreased by increasing air mass flow rates. Maximum efficiency of $51 \%$ was recorded for a tilt angle of $35^{\circ}$ at natural flow rate which decreased $24 \%$ by optimizing the flow to $3.03 \mathrm{kgs}^{-1}$. The minimum efficiency of $43 \%$ was recorded for tilt of $50^{\circ}$ at natural flow which decreased to $19 \%$ at maximum flow rate of $3.03 \mathrm{kgs}^{-1}$. The exergy decrease is due the heat flowing towards the dryer and storage tank by agent fluids. Exergy was maximum at $35^{\circ}$ tilt angle because of the normality of solar irradiance at this angle on the absorber plate of the solar collector. The results are in argument of Farahat et al. (2009) who reported decrease in exergetic efficiencies

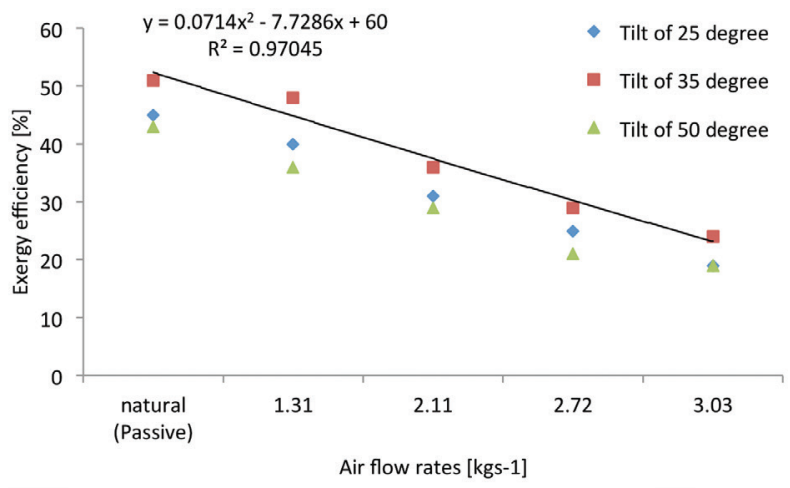

FIGURE 7. Exergetic efficiencies of the flat plate solar collector as affected by air mass flow rates and tilt at different tilts of the solar collector 
of a flat plate solar collector with increase in tilt angle and increase in air mass flow rates. Ge et al. (2014) and Hanif et al. (2016) also reported in their results that exergy decreased with increased in air mass flow rates.

\section{OVERALL EFFICIENCY}

Experimental data regarding the efficiency of flat plate solar collector to convert energy to useful exergy is given in Figure 8. The data shows that the efficiencies of the flat plate solar collector increased by increasing air mass flow rates. Minimum efficiency of 59\% was recorded for a tilt angle of $35^{\circ}$ at natural flow rate which increased to $71 \%$ by optimizing the flow to $3.03 \mathrm{~kg}$. $\mathrm{s}^{-1}$. The minimum efficiency of $56 \%$ was recorded for tilt of $50^{\circ}$ at natural flow which increased to $64 \%$ at maximum flow rate of $3.03 \mathrm{kgs}^{-1}$. The increase in overall efficiency is due the heat uptake by the flowing air towards the dryer and as a working agent fluid. Less heat was leaked and lost at higher air mass flow rates. Efficiency was maximum at $35^{\circ}$ tilt angle because the solar irradiance was normal at this tilt at the site, receiving maximum solar energy. The results of efficiency as affected by different air mass flow rates and tilt angles is are in accordance with the findings of Hanif et al. (2016) and Koca et al. (2014) who reported increase in efficiencies of a flat plate solar collector with increase in air mass flow rates. Calise et al. (2016) and Hamed et al. (2014) also reported in their results that efficiency increase with increased in air mass flow rates. The overall efficiency of the collector tested in the present experiment is $20 \%$ higher than the solar collectors used in the literature.

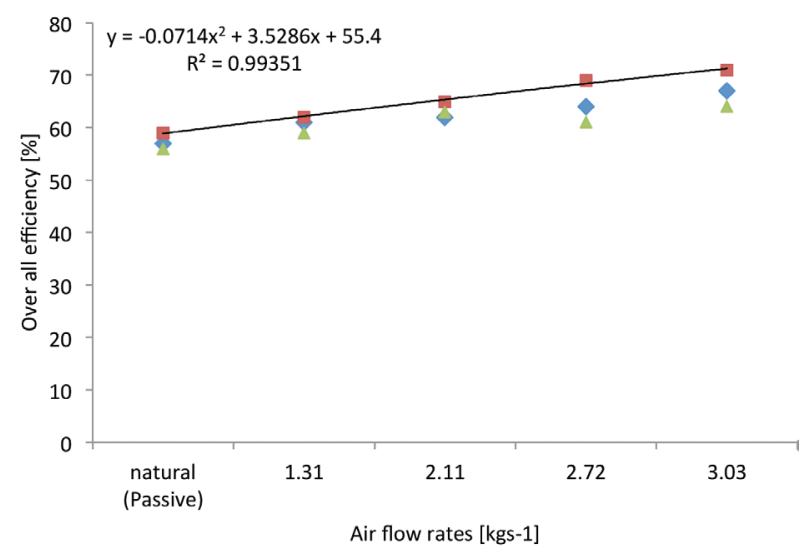

FIGURE 8. Overall efficiencies of the flat plate solar collector as affected by air mass flow rates and tilt at different tilts of the solar collector

\section{CONCLUSION}

It was concluded that energy and overall efficiencies of the solar collector increase while exergy efficiency decreased with increasing air mass flow rates inside the collector under a constant tilt angle. In tilting the solar collector gave better results at $35^{\circ}$ tilt. Based on the efficiencies, the collector must be operated at high air mass flow rate of 3.03 $\mathrm{kgs}^{-1}$ under $35^{\circ}$ tilt angle to achieve maximum performance from it as a dryer for drying carrots.

\section{ACKNOWLEDGEMENTS}

The authors acknowledge the funding provided by the Higher Education Commission of Pakistan (HEC-PAK) for the Research under the project "comparison of flat plate and parabolic trough solar collector for drying and water heating purposes". The authors also acknowledge the support and help provided by the University of Agriculture Peshawar Pakistan and Nuclear Institute for Food and Agriculture Peshawar Pakistan during the research study.

\section{REFERENCES}

Al-Sulaiman, F.A. 2014. Exergy analysis of parabolic trough solar collectors integrated with combined steam and organic Rankine cycles. Energy Conversion and Management 77: 441-449.

Bellos, E., Tzivanidis, C. \& Antonopoulos, K.A. 2016. Exergetic, energetic and financial evaluation of a solar driven absorption cooling system with various collector types. Applied Thermal Engineering 102(1): 749-759.

Calise, F., d'Accadia, M.D., Macaluso, A., Piacentino, A. \& Vanoli, L. 2016. Exergetic and exergoeconomic analysis of a novel hybrid solar-geothermal polygeneration system producing energy and water. Energy Conversion and Management 115(1): 200-220.

Farahat, S., Sarhaddi,F. \& Ajam, H. 2009. Exergetic optimization of flat plate solar collectors. Renewable Energy 34(3): 11691174.

Ge, Z., Wang, H., Wang, H., Zhang, S. \& Guan, X. 2014. Exergy analysis of flat plate solar collectors. Entropy 16(6): 25492567.

Hamed, M., Snoussi, A. \& Brahim, A.B. 2014, March. Energy and exergy analysis of flat plate solar collectors in transient behaviors. In Renewable Energy Congress (IREC), 2014 5th International IEEE. pp. 1-6.

Hanif, M., Khattak, M.K., Amin, M., Ramzan, M., Zakir, S., Ullah, S. \& Khan, Z. 2016. Development of an efficient flat plate solar air heater for drying and water heating purposes. Sains Malaysiana 45(3): 489-497.

Hanif, M., Khattak, M.K., Rahman, M., Khan, M., Amin, M. \& Ramzan, M. 2014. Performance evaluation of a flat plate solar collector as a drier for chillies and tomatoes. J.Sci.Tech. and Dev. 33(2): 63-67.

Islam. S., Dincer. I. \& Yalbas, B.S. 2015. Energetic and exergetic performamce analysis of a solar energy-based integrated system for multigeneration including thermoelectric generators. Energy 93: 1246-1258.

Jafarkazemi, F. \& Ahmadifard, E. 2013. Energetic and exergetic evaluation of flat plate solar collectors. Renewable Energy 56: 55-63.

Kalogirou, S.A., Karellas, S., Badescu, V. \& Braimakis, K. 2016. Exergy analysis on solar thermal systems: A better understanding of their sustainability. Renewable Energy 85: 1328-1333.

Koca, A., Oztop, H.F., Koyun, T. \& Varol, Y. 2008. Energy and exergy analysis of a latent heat storage system with phase 
change material for a solar collector. Renewable Energy 33(4): 567-574.

Muhammad Hanif* Mansoor Khan Khattak \& Muhammad Ramzan

Department of Agricultural Mechanization The University of Agriculture Peshawar

25130, Khyber Pakhtunkhwa

Pakistan

Maazullah Khan

Nuclear Institute for Food and Agriculture

25130 Peshawar

Pakistan
Abdurab

Department of Horticulture

The University of Agriculture Peshawar

25130 Khyber Pakhtunkhwa

Pakistan.

*Corresponding author; email: hanif_mechanization@aup.edu.pk

Received: 3 April 2017

Accepted: 14 November 2017 